\title{
O ENSINO REFLEXIVO NA FORMAÇÃO DO ENGENHEIRO AGRÔNOMO: UM ESTUDO DE CASO NA FITOTECNIA
}

\section{REFLECTIVE TRAINING OVER THE AGRONOMIST EDUCATION: A PLANT SCIENCE CASE STUDY}

\author{
Marcos Vinicius Ribas MILLÉO \\ Orientador: Professor Dr. Luiz DONI FILHO (Departamento de Fitotecnia e Fitossanitarismo - UFPR)
}

\section{RESUMO}

A ciência e a tecnologia evoluíram de forma significativa, dentro de uma filosofia global, modelos de ensino, pesquisa, e trabalho foram adotados como possíveis soluções para os problemas da sociedade, mas sem a força transformadora necessária, pois observa-se a continuidade dos problemas das classes menos favorecidas. $O$ engenheiro agrônomo incorporou as inovações e exigências da modernização, objetivando atender as necessidades de grupos restritos que determinam como deve ser o processo produtivo dentro desta realidade. Porém a formação voltada para o desempenho, o conhecimento das técnicas, e o cumprimento de metas e objetivos previamente propostos, distanciou o engenheiro agrônomo dos meios urbano e da pequena propriedade rural que desenvolve a agricultura de subsistência, a agricultura social, que não foram mais contemplados com soluções para as suas necessidades. A sociedade urbana tem uma idéia errônea e parcial sobre o engenheiro agrônomo que é a de vendedor de agrotóxicos vinculando indevidamente o exercício da agronomia como algo ruim, contra o meio ambiente e a saúde das pessoas. $O$ engenheiro agrônomo continua a ser formado com base numa abordagem pedagógica tradicionalista, em que os conhecimentos técnicos são repassados por especialistas. O modelo de ensino de agronomia brasileiro não possibilita a capacitação profissional em implementar alternativas eficazes diante da crise e dos problemas da atualidade, necessários para responder aos desafios e demandas atuais dos diferentes setores da nossa sociedade. A educação é um processo intencional e a ação educativa uma prática exercida por professores em situações planejadas, portanto é possível ocasionar mudança de atitude nos acadêmicos, formando além de profissionais, cidadãos mais comprometidos com a realidade social, econômica, ambiental e política em que vivemos. Este trabalho foi desenvolvido durante o desenrolar dos conteúdos da disciplina "Agricultura I" do Curso de Agronomia da Universidade Estadual de Ponta Grossa no primeiro semestre de 1998 e 1999 e teve por objetivos, possibilitar a mudança de atitude dos alunos trabalhando-se com conhecimentos, habilidades e atitudes alicerçados numa metodologia fundamentada na formação reflexiva crítica, buscando assim uma contribuição maior do ensino de fitotecnia através do estudo da agricultura para a formação acadêmica, abordado através da construção do conhecimento. Após o término dos trabalhos foram realizadas avaliações no final do período, aos seis meses e um ano, a fim de se verificar se os conhecimentos, habilidades e atitudes de caráter social e humano permanecem, se ampliam ou se diluem ao longo do curso e se esta nova maneira de trabalhar contribui para o desenvolvimento de melhores profissionais e cidadãos. Verificou-se que os conceitos não se alteram e apesar das dificuldades de se implantar uma metodologia que permita uma formação reflexiva crítica por meio da construção do conhecimento, o trabalho é viável, e uma vez iniciado, seus efeitos são irreversíveis e são a chave quando se pensa na construção de um aluno reflexivo e criador e na formação de um professor sujeito de seu ensino e comprometido com a mudança.

\section{ABSTRACT}

Science and technology have evolved significantly within a global philosophy; models of teaching, research and work have been adopted as possible solutions for the problems of society, but they lack the necessary changing power, as we observe the continuation of the problems among the underprivileged classes, the agronomist has incorporated the innovations and demands of modernization with the aim of meeting the needs of restricted groups wich determine how the production process must be within this context. However, training which is oriented toward performance, know-how. and the accomplishment of goals and objectives proposed a prior has set the agronomist apart from the urban society, and from the small farms that practice subsistence farming, the social agriculture, which were no longer provided with solutions for their needs. The urban society has a misconcceived and partial view about the agronomist, namely, that he is a vendor of agrochemicals, unduly labeling the practice of agronomy as something bad, against tho environment and health of people. The agronomist continues to be trained on the basis of e traditionalist pedagogical approach, in which the technical knowledge is passed on by specialists. The Brazilian model of agronomy teaching does not provide for the building of professional capacity towards implementing effective alternatives in face of the crisis and the problems of today, alternatives which are needed to respond to the current challenges and demands of the different sectors of our society. Education is an intentional process, and educational action is e practice conducted by teachers in planned settings: therefore, it is possible to bring about a charge of atittude in the students, preparing, in addition to professionals, citizens who are committed to the social, economic, environmental and political reality in which we live. This work was carried in tihe progress of the program of the discipline "Agdculture 1" of the Agronomy Course at Ihe State University of Ponta Grossa in the first semesters of 1998 and 1999, and aimed to facilitate a change of attitude in the students working with knowledge, skills and attitudes grounded in a methodology founded on a training for critical thinking, thus seeking a greater contribution of plant science teaching through the study of agriculture for the academic training as approached trough knowledge construction. After the closing of the activities, evaluations were conducted of the end of the term, at six months and one year, in order to find out wether the body of the knowledge, skills and attitudes of social and human character remain unchanged, are enhanced, or diluted throughout the course, and wether this new way of working contributes to the development of better professionals and citizens. It was found that the concepts do not change, and despite the difficulties in putting in place a methodology which allows for critical thinking training by means of knowledge construction, the work is feasible, and, once initiated, its effects are irreversible, and they are also the key factor when one considers tine construction of a reflective and creative student, and the shaping of a teacher who is the subject of his teaching and commited to the change. 